\title{
Sales Prospecting Framework: Marketing Team, Salesperson Competence, and Sales Structure
}

Valter Afonso Vieira ${ }^{1}$

Danny Pimentel Claro ${ }^{2}$

\footnotetext{
${ }^{1}$ Universidade Estadual de Maringá, Maringá, PR, Brazil
} ${ }^{2}$ INSPER Instituto de Ensino e Pesquisa, São Paulo, SP, Brazil

Received 12 April 2020. This paper was with the authors for two revisions. Accepted 29 December 2020.

First published online 21 January 2020.

Editor-in-chief: Carlo Gabriel Porto Bellini (DD (Universidade Federal da Paraíba, João Pessoa, PB, Brazil) Associate editor: Salomão Alencar de Farias (D) (Universidade Federal de Pernambuco, Recife, PE, Brazil)

Reviewers: Vinicius de Andrade Brei (D) (Universidade Federal do Rio Grande do Sul, Porto Alegre, RS, Brazil), Marcos Severo (D) (Universidade Federal de Goiás, Goiânia, GO, Brazil) and Leandro Guissoni (iD (Fundação Getulio Vargas, São Paulo, SP, Brazil)

Editorial assistants: Kler Godoy and Simone Rafael (ANPAD, Maringá, PR, Brazil) 


\section{ABSTRACT}

Sales management is an integral part of virtually all market exchanges. Marketing team, sales opportunities, salesperson skills, firm sales resources, digital platforms, and sales compensation plan create a marketing-salesperson-firm dynamic underlying the sales prospecting framework. Firm's managers continuously strive to deal with these manifold elements of such dynamic context. This article offers an overview of the sales prospecting effort and sheds light on how firms generate superior performance by managing three interconnected elements. The marketing team (e.g., generating leads), salesperson competence (e.g., individual and team competence), and the firm being ready to deploy sales structure (e.g., sales platform) result in superior performance. By thinking outside the box, the authors propose the Salespeople Prospecting Framework with multiple associations based on previous marketing, sales, and retail research. The authors discuss implications for managing the sales funnel and offer suggestions for further research investigation.

Keywords: marketing; sales; funnel; performance; prospect

JEL code: JEL nonadherent. 
With changes in the business landscape in recent years due to social media sales, consumers' online purchases and in-store pick up, inbound marketing activities (Vieira, Almeida, Agnihotri, Silva, \& Arunachalam, 2019), big data and analytics, and artificial intelligence, firms have embraced salespeople to truly engage with their customers. Salespeople employ sales knowledge and tactics to transform prospects into customers generating profitable customer relationships over the years. Industry reports have suggested that total spending on lead generation tools has increased worldwide and that sales supporting platform drives efficiency gains in sales activities; for example, Helsinki-based Leadfeeder raised $€ 3.1$ million to automate lead generation (Loritz, 2019). According to Hubspot, about 50\% of customers rely on customer references and industry reports to make purchase decisions, which enforces challenges for any prospecting effort (Davies, 2020). Firms then need to recognize the prominence of deploying marketing lead generation tools, working in teams, nurturing salespeople's competencies, and investing in sales structure. In the management domain, these business changes underlie our proposed sales prospecting framework that encompasses the following elements: marketing teams, salesperson competence, and sales structure.

Following sales literature, sales management refers to firm's sales operations that include managing salespeople and their managers, implementing technology tools to assist multiple activities, such as delivering, ordering, and managing customer account (Weitz \& Bradford, 1999). As part of sales management, sales prospecting focuses on initiating and developing new lead and moving on to a qualified prospect, designing the sales proposal, dealing with objections, and closing the sales opportunity (Sabnis, Chatterjee, Grewal, \& Lilien, 2013). By revising previous sales research and empirical evidence, we identified three key elements to propose the sales prospecting framework (Figure 1, Panel A). The three elements stress the importance of the marketing team (e.g., leads and sales plan), salesperson particular prospecting competence (e.g., individual and team competencies), and sales structure (e.g., sales platform, ERP, CRM, and firm process). Our ultimate goal is to present how these elements are important for sales prospecting and how they are related to sales performance.

While sales prospecting follows a course of action from the consumer's need to the marketing intelligence records, and from the salesperson-customer approach to firm processes and resources, there is a lack of comprehensive outlook on how sales prospecting develops because existing literature is disperse (Hartmann, Wieland, \& Vargo, 2018). Moreover, few studies carefully accounted for an integrated view of marketing team effort toward sales prospecting, salesperson particular prospecting competence, and the fully deployed processes and resources in the sales structure. We surely take this unique opportunity to deepen our understanding on the sales prospecting framework, offering conceptual definitions of main elements, highlighting key studies, managerial implications, and gaps for further research in the field of management. We begin our discussion with prospecting driven marketing key roles of lead generation and sales planning (Cano, Carrillat, \& Jaramillo, 2004). Next, we elaborate on salespersons competence and end with firm's sales structure (Figure 1, Panel A). 


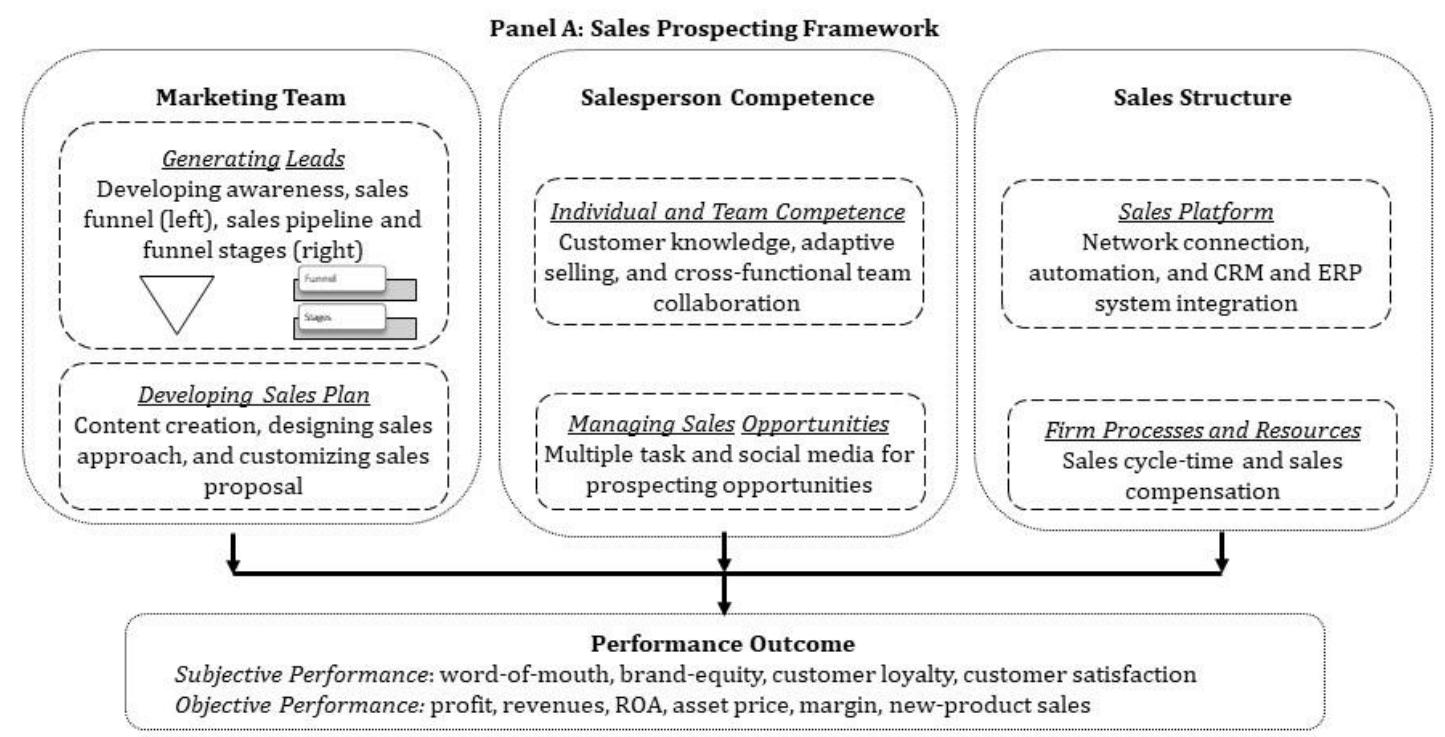

Objective Performance: profit, revenues, ROA, asset price, margin, new-product sales

Panel B: Sales Funnel (left) and Marketing Process according to the Funnel Stages (right)
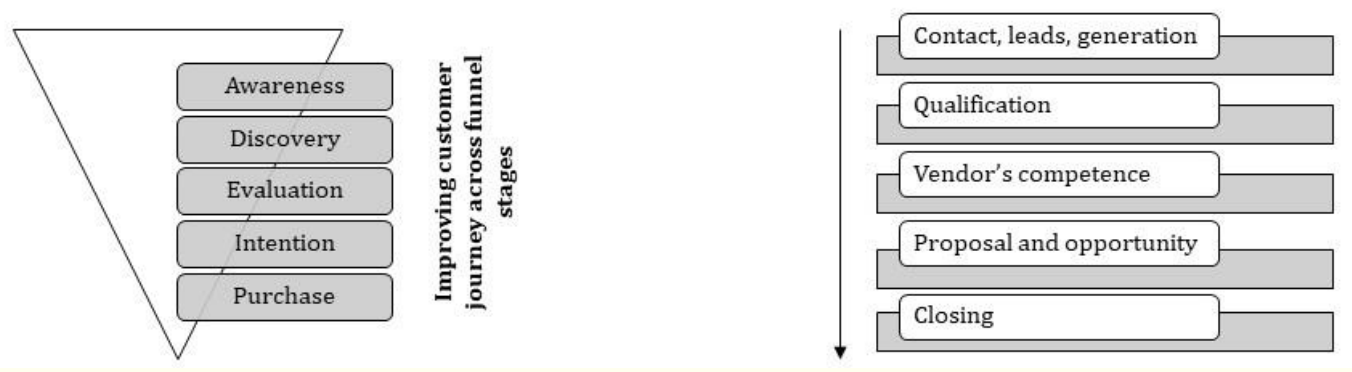

Figure 1. Sales prospecting framework

\section{MARKETING TEAM}

Prospecting marketing team manages lead generation, dissemination, and creation of market response to customer and competitor movements. Previous investigation found that this team influences long-term future shareholder returns and short-term return on assets (Feng, Morgan, \& Rego, 2015) due to firm-level marketing capability (Morgan, Feng, \& Whitler, 2018). According to Feng, Morgan, and Rego (2015), marketing team is accountable for developing two firm-level marketing capabilities - (a) build long run market-based assets, and (b) leverage these market-based assets in the short run to deliver cash-flows -, which in turn impacts shareholder returns and return on assets. Market-oriented firms benefit from a strong marketing function, but a powerful marketing team cannot compensate for low levels of firm's market orientation (Götz, Hoelter, \& Krafft, 2013). Firms have invested a large amount of money on customer orientation (e.g., Nike invested US\$ 1.44 billion in 2018) in order to create marketing processes for supporting lead generation (i.e., identifying customers with interest or enquiries about products or services) and developing sales plans and ultimately increase firm profit.

When firms have a customer-oriented marketing team, they can identify new leads and aid qualify leads into prospect buyers leveraging salesperson competence, planning the sales approach, and

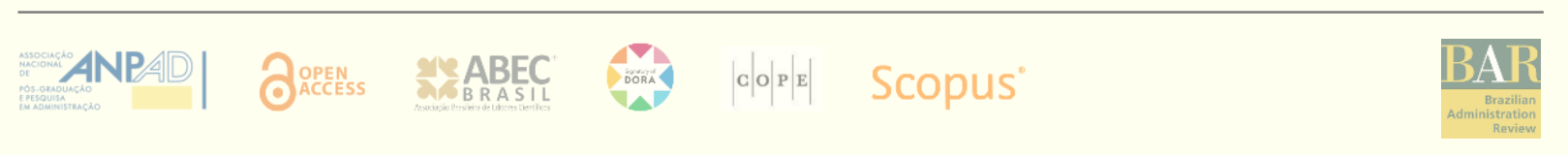


using processes (Andzulis, Panagopoulos, \& Rapp, 2012) and resources to ultimately convert them into loyal customers (Vieira, Faia, Boles, Marioti, \& Pereira, 2019). The large marketing team in many firms is primarily responsible for the strategy of prospecting that may include numerous goals, for example, content creation, developing marketing tactics, planning the sales approach, selecting keywords in Google search, email marketing, defining investments in social media, and advertising in on- and off-line channels. Search engine optimization is a way for firms to effectively prospect customers and has become a very large market reaching over $\$ 80$ billion according to Forbes (Voskresensky, 2019). However, the prospecting driven marketing effort needs to add key tasks to properly (a) generate leads and (b) develop sales planning to the individual salesperson and marketing teammates (Figure 1, Panel B-right).

First, lead generation encompasses sales funnel processes (Figure 1, Panel B-left) of discovering and developing awareness of potential buyers about products and services (Sabnis et al., 2013). Specialized digital agencies (e.g., ClickFunnels) help lead generation by implementing creative communication to drive product up- and cross-sell and one-time promotions. The marketing team often searches leads and adds them to the sales funnel for salespeople to take over and ascertain the real sales potential (Paschen, Wilson, \& Ferreira, 2020). Salespeople can use their competence to appraise and qualify the sales lead and remove unpromising ones. Salespeople then can contact the qualified potential buyer to carry on a sales presentation using customized content (e.g., inbound marketing) by the marketing team aiming to increase purchase intention. When the potential buyer positively responds, salespeople move them down into the sales funnel system by opening a sales opportunity in the firm's records. Salespeople present to a potential buyer the sales proposal based on his/her particular demand, and eventually close the sales opportunity. This marketing-sales integrated process is assisted by the sales funnel process and system (Strong, 1925; Wiesel, Pauwels, \& Arts, 2011). According to recent marketing-sales integration survey, $68 \%$ of respondent firms have neither clearly defined nor properly assessed their sales funnel, showing that $79 \%$ of marketing leads are never converted into customers (Schmitz, 2020).

Based on Figure 1 (see Panel B-right), research suggests that the use of marketing developed sales influences tactics in customer encounters to increase lead generation and qualification and facilitate the flow into the sales funnel (Pöyry, Parvinen, \& McFarland, 2017). By providing support for lead generation, the marketing team designs the first approach to potential customers (Capon, Farley, \& Hoenig, 1990; Monteiro \& Vieira, 2016), analyzing and selecting qualified leads, and then moving them to salesperson's CRM system (Bradford, Johnston, \& Bellenger, 2016). The marketing team becomes responsible for guiding the business process, developing proposals, and ensuring the customer-centric orientation when managing customer leads through the sales funnel in the CRM system (Raman, Wittmann, \& Rauseo, 2006).

By being customer-centric, marketing team facilitates the customer journey through a variety of touch points across online and offline channels on his/her paths to purchase (Venkatesan, Petersen, \& Guissoni, 2018). Along the customer journey through touch points in manifold channels and media, marketing and salespeople need "to integrate multiple business functions, and even external partners, in creating and delivering positive customer experiences" (Lemon \& Verhoef, 2016, p. 69). According to Forbes, brands that have greater customer journey experience 
carry in 5.7 times more sales (Spencer, 2019). The sales funnel also provides to salespeople a clear view of the potential buyer stage, starting with lead, moving to prospect, and customer conversion (Cooper \& Budd, 2007). In addition to Figure 1 (see Panel B-left), previous study suggests different ways of defining the sales funnel, such as 'awareness-interest-decision-action,' 'prospectcontacts-leads-finalists-client,' and others (Söhnchen \& Albers, 2010). The marketing team is accountable for defining the sales funnel sequence and spawning leads according to its sales plan.

Second, sales planning as a prospect marketing focus refers to the process of stimulating potential buyers with the main goal of moving them down the sales funnel (Jolson \& Wotruba, 1992). The sales plan provides salespeople with knowledge of how they should manage their time (Bashaw, Ingram, \& Keillor, 2002) and skills and commit with specific leads who have greater chance to buy the product while avoiding "allocating time to leads that represent casual inquires" and waste of time (Sabnis et al., 2013, p. 55). Some leads may not be prepared to buy, and other leads may not actually be interested in buying because the marketing team sources a large number of leads. After the marketing team generates leads and defines the sales plan, salesperson competence in transforming these leads into 'win' become the challenge. Salespeople need to use their competence to manage the sales pipeline, describing the details of sales prospects and where they are in the purchase stage and how salespeople can close the opportunity. Salespeople's effort on lead conversion has a positive impact on the number of opportunities closed in the sales funnel (Bradford et al., 2016). The rationale underlying the marketing developed sales plan is to provide support for considering all customer's information (Söhnchen \& Albers, 2010) and creating customized content assisting salespeople in the sales prospecting approach (Saegert \& Hoover, 1980).

\section{SALESPERSON COMPETENCE}

According to the extensive meta-analysis conducted by Verbeke, Dietz, and Verwaal (2011), salesperson competence includes dispositional traits (e.g., extraversion), identity (e.g., selfperceived ethic), cognitive and affective abilities, and adaptive selling (Alavi, Habel, \& Linsenmayer, 2019; Román \& Iacobucci, 2010). We also acknowledge other competences, such as solution-related activities (Koponen, Julkunen, \& Asai, 2019), coping and emotional competence (Verbeke, Belschak, \& Bagozzi, 2004), and communication competence (Böhm, Eggert, Terho, Ulaga, \& Haas, 2020). Salespeople with high levels of sales competence can properly deal with customer conflicts (Locke, Smith, Erez, Chah, \& Schaffer, 1994), work engagement, skills, and self-efficacy (Lacoste, 2018). In our sales prospecting framework, we focus on salesperson competence from two complementary perspectives, (a) individual and team competences, and (b) sales opportunity management.

First, individual and team salespeople competence of assessing customer knowledge increases new consumer buying behavior (e.g., omnichannel cross-buying), cross- and up-selling (Johnson \& Friend, 2015), and customer acquisition and retention (Vieira, Faia, et al., 2019). Customer knowledge refers to the richness of information "that salespeople use in selling the products and services” (Verbeke, Dietz, \& Verwaal, 2011, p. 411). Salespeople, who develop competence to access serious information stored in other functional departments (e.g., HR and accounting),

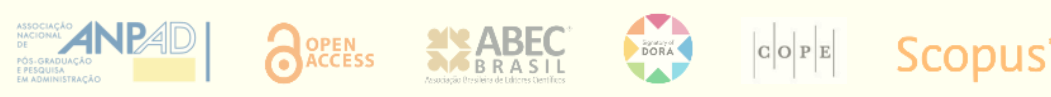


increase sales performance (Claro \& Ramos, 2018; Claro, Ramos, Gonzalez, \& Palmatier, 2020). Moreover, the collaboration with team members and colleagues in other functions enhances the impact of customer knowledge on sales performance (Gonzalez \& Claro, 2019). The salesperson's network competence is key to gain information about product features and consumer demands, and in turn supports prospecting activities (Claro, Laban Neto, \& Claro, 2013; Gonzalez, Claro, \& Palmatier, 2014).

Second, managing sales opportunity is critical for sales prospecting activities. The number of sales opportunities opened is intimately related to the quality of lead generation. Only about $30 \%$ of the number of opportunities identified by marketing converts into an effective sale (Michiels, 2009). Salespeople then manage several sales opportunities at the same time and need to select the promising ones. Managers play a transactional and transformational leadership behavior (Vieira, Negreiros, Agnihotri, \& Bakeshloo, 2020; Vieira, Perin, \& Sampaio, 2018) and may influence salesperson's decision of managing opportunities and self-efficacy. In considering the business sales cycle year, salespeople strive to allocate their time according to the multiple tasks of transforming opportunities into sales (Zoltners \& Sinha, 1980). Multiple tasks include developing new opportunities, presenting offers, explaining warranty, and suggesting different prices (Brei, d'Avila, Camargo, \& Engels, 2011) and product attributes. In addition, sales opportunities can be achieved by promoting products and offers via social media (Andzulis et al., 2012). LinkedIn, Facebook, Instagram, Twitter, and WhatsApp are some of the social media available for salespeople to interact with customers, generate engagement (Almeida, Coelho, Camilo-Junior, \& Godoy, 2018), and develop new opportunities.

\section{SALES STRUCTURE}

To promote sales prospecting activities, firms devoted considerable attention to sales structure. In recent years, it has become feasible to invest in electronic sales platforms fostering automation and integration of systems, and also effectively tracking sales cycle time and salesperson compensation (Basu, Lal, Srinivasan, \& Staelin, 1985). Firms provide sales platforms as resources for helping salespeople manage the customer portfolio (e.g., Personal Capital, Morning Star, Mint). Sales platforms include software that supports face-to-face as well as online customer relationships. Face-to-face platforms also includes software designed to use network connection (Claro et al., 2013; Mitrega, Forkmann, Ramos, \& Henneberg, 2012), geomarketing content (e.g., geotargeting), artificial intelligence (e.g., image recognition), and search engine mechanisms. Some of the widespread sales platforms include Salesforce, HubSpot, ActiveCampaign, Zoho, MSDynamics, and Pipedrive. Additionally, resources for online sales platforms need to be integrated with the execution of marketing strategy, such as inbound and outbound marketing, direct marketing (e.g., Kuno, Stream Creative, Weidert Group), and social media (e.g., LinkedIn Sales Navigator). For some firms, the processes and resources must be properly integrated with online retailers as they grow in sales (e.g., Magalu, Americanas). The access to valuable information becomes critical for salespeople to understand consumer off- and on-line purchase behavior. 
Firms need to assure the provided resources are fully automated and integrated such as the ERP system with CRM sales platforms. By implementing smart CRM functionalities, salespeople gain time not having to enter data into the system. For instance, the salesperson's calendar and customer visits can be integrated, as well as geolocalization can serve as a way to check in the salesperson in the customer office. Business reports show that CRM system is relevant and can change the way that salespeople "are spending a mere 37\% of their time actually selling and 63\% on everything else" (Voskresensky, 2019). Additionally, there are benefits from the integration of order processing with the production process, customer relationship with the financial department, customer knowledge data with R\&D (Gonzalez \& Claro, 2019), and product sales with product inventory. For example, the CRM system keeps customer sales records organized, but the salespeople do not track customer orders and cannot promptly respond to the customer about product information. This lack of automation and integration damages firm performance. Integrating ERP system with CRM sales also helps firms develop efficient sales processes and customer relationship toward informative reports, smart queries, and performance dashboards. Previous research shows the importance of using data from CRM system to develop equitable salespeople ranking and create best practices sharing program (Claro \& Kamakura, 2017). Moreover, integrating HR system with CRM sales helps salespeople follow their sales compensation (Bommaraju \& Hohenberg, 2018), bonus (Chung, Steenburgh, \& Sudhir, 2013), commission, prizes, and reward accomplished as well as tacking the coherence between their targets and firm goals. Although some sales compensation plans are well defined, salespeople may try to 'play' the system (Basu et al., 1985). For instance, some salespeople may reach the quota before sales cycle year ends (Locke, Latham, \& Erez, 1988), which may indicate that these salespeople could be generating new sales in the current cycle year. However, entering such new sales into next cycle year records might provide better gains for the salesperson (Peterson, Rodriguez, \& Krishnan, 2011). By keeping a close look at the records and compensation design, the firm can help salespeople realize the goals in an earlier time, generating consequently greater sales.

Firm processes and resources may also influence performance because of opportunity sales cycle time. The cycle time refers to the time since the first contact with the potential buyer or when identifying a sales opportunity for an existing client to converting it into a win. The earlier the sales cycle time ends, the earlier salespeople achieve their quota, goals, and attain firms' performance (Bradford et al., 2016). Organizations need to be vigilant for long cycle time because $57 \%$ of salespeople expect to miss their quotas in 2019, according to Salesforce's Annual State of Sales survey (Voskresensky, 2019). Research on sales cycle time is scarce and offers different influences on salespeople's performance (Sabnis et al., 2013). Previous studies have suggested how to reduce sales cycle time by considering new product development, $R \& D$, and marketing investments (Bashaw et al., 2002; Voskresensky, 2019).

Attempting to reduce sales cycle time may eventually have negative effects on salesperson's compensation and consequently on performance outcome (Chung et al., 2013). This viewpoint is interesting because it reveals to firms, sales managers, and customers the importance of sales quality, rather than sales speed. Few investigations have been on how sales cycle time generates negative effects on product return, default, salespeople fatigue, mental illness, stress, customer

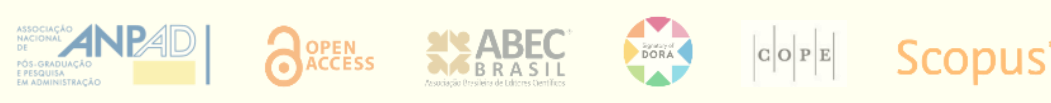


complaints, sales team conflict, and salespeople's frustration in not obtaining the bonus, rewards, and prizes (Chung et al., 2013). These negative consequences can explain why only 53\% of salespeople are meeting their quotas and reducing performance outcome, according to CSO Insights’ 2017 World-Class Sales Practices study (Spencer, 2019).

\section{FUTURE DIRECTIONS}

To account for recent business developments and advance firm performance outcome, we propose and discuss a sales prospecting framework including key elements of (a) marketing team, (b) salesperson competence, and (c) sales structure. We recognize, and elaborate on previous sections, the interplay between these elements and how firms can generate greater levels of revenues and profits. The interplay between these elements happens because marketing team generates leads and develops sales plan that is leveraged by salesperson's competence on sales knowledge, adaptive selling, cross-functional collaboration, and abilities for multi-task activities, such as social media, prospecting, and customer acquisition. The marketing team and salesperson rely on the sales structure to use the sales platform, processes, and resources. The sales structure is in turn designed by the marketing team and based on the salespeople's knowledge. Such intertwined elements result in more effective sales prospecting efforts and consequently increase firm performance. Further research can dedicate additional work to empirically test specific effects of the elements or the entire framework. We identify three main streams of research opportunities for future investigation.

First, research into digital sales platforms could deepen our understanding of how salespeople gain effectiveness into prospecting efforts. As such platforms have become popular in sales organizations, researchers have the opportunity to collect long historic data to shed light on particular tactics and sales prospecting best practices. For instance, identifying how timely salesperson responds to the lead and what kind of customized content has the most performance impact. Matching salesperson prospecting efforts with customer and market specificities can help researchers and managers plan and effectively execute the prospecting strategy. This additional research can contribute to sales management literature by showing how social media platform boosts sales via effective lead generation effort.

Second, business social media has offered vast promise for quite some time and those promises are just beginning to be realized. The dynamic movement of records in the sales funnel has never been so easy to collect. Many firms now use social media like LinkedIn to find and approach contacts as potential customers. Salespeople have been active in gathering critical information to warm the cold call approach. Researchers can draw historical behavioral data from such social media and enrich that with customer, salespeople, and market data. This may help predict interesting pattern of sales funnel progression and, most importantly, inform sales research and managers on how to efficiently manage sales prospecting efforts. This steam of research opportunity will shed light on how firms need to manage their echoverse social media model to increase sales touch and conversion (Vieira, Almeida, et al., 2019). 
Third, it remains a challenge for firms to integrate software systems (e.g., CRM, ERP) as they are hardly implemented as one full piece. These systems can have positive impact on customer relationship, whether offline or online. Firms in consumer-packaged goods targeting traditional medium and small retailers have developed automated self-service online order platforms. This releases salesperson from transactional duties and enables them to improve customer service. Such system integration suggests a host of research possibilities. Studies could pursue a better understanding of the short- and long-term benefits and consequences of different software systems supporting sales prospecting efforts. This steam of research can contribute to sales management literature by suggesting how software can be designed to leverage network connection (Claro et al., 2013; Mitrega et al., 2012), geomarketing content, geotargeting, artificial intelligence (e.g., image recognition), and search engine optimization mechanisms.

\section{ACKNOWLEDGMENTS}

The authors would like to thank the editor, the associate editor and the referees for their constructive comments.

\section{REFERENCES}

Alavi, S., Habel, J., \& Linsenmayer, K. (2019). What does adaptive selling mean to salespeople? An exploratory analysis of practitioners' responses to generic adaptive selling scales. Journal of Personal Selling $\mathcal{E}$ Sales Management, 39(3), 254-263. https://doi.org/10.1080/08853134.2019.1642765

Almeida, M., Coelho, R., Camilo-Junior, C., \& Godoy, R. (2018). Quem lidera sua opinião? Influência dos formadores de opinião digitais no engajamento. Revista de Administração Contemporânea, 22(1), 115-137. https://doi.org/10.1590/1982-7849rac2018170028

Andzulis, J. M., Panagopoulos, N. G., \& Rapp, A. (2012). A review of social media and implications for the sales process. Journal of Personal Selling $\mathcal{E}$ Sales Management, 32(3), 305-316. https://doi.org/10.2753/PSS08853134320302

Bashaw, R. E., Ingram, T. N., \& Keillor, B. D. (2002). Improving sales training cycle times for new trainees: An exploratory study. Industrial Marketing Management, 31(4), 329-338. https://doi.org/10.1016/S0019. 8501(01)00166-3

Basu, A. K., Lal, R., Srinivasan, V., \& Staelin, R. (1985). Salesforce compensation plans: An agency theoretic perspective. Marketing Science, 4(4), 267-291. https://doi.org/10.1287/mksc.4.4.267

Böhm, E., Eggert, A., Terho, H., Ulaga, W., \& Haas, A. (2020). Drivers and outcomes of salespersons' value opportunity recognition competence in solution selling. Journal of Personal Selling $\mathcal{E}$ Sales Management, 40(3), 180197. https://doi.org/10.1080/08853134.2020.1778484

Bommaraju, R., \& Hohenberg, S. (2018). Self-selected sales incentives: Evidence of their effectiveness, persistence, durability, and underlying mechanisms. Journal of Marketing, 82(5), 106-124. https://doi.org/10.1509/jm.17.0002

Bradford, W., Johnston, W. J., \& Bellenger, D. (2016, September). The impact of sales effort on lead conversion cycle time in a business-to-business opportunity pipeline. Proceedings of the International Engaged Management Scholarship Conference, Paris, France, 6. https://doi.org/10.2139/ssrn.2866954

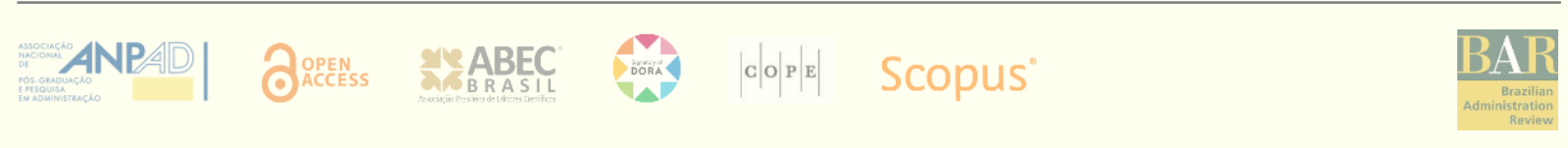


Brei, V. A., D'Avila, L., Camargo, L. F., \& Engels, J. (2011). The influence of adaptation and standardization of the marketing mix on performance: A meta-analysis. Brazilian Administration Review, 8(3), 266-287. https://doi.org/10.1590/S1807-76922011000300004

Cano, C. R., Carrillat, F. A., \& Jaramillo, F. (2004). A meta-analysis of the relationship between market orientation and business performance: Evidence from five continents. International Journal of Research in Marketing, 21(2), 179. 200. https://doi.org/10.1016/j.ijresmar.2003.07.001

Capon, N., Farley, J. U., \& Hoenig, S. (1990). Determinants of financial performance: A meta-analysis. Management Science, 36(10), 1143-1159. https://doi.org/10.1287/mnsc.36.10.1143

Chung, D. J., Steenburgh, T., \& Sudhir, K. (2013). Do bonuses enhance sales productivity? A dynamic structural analysis of bonus-based compensation plans. Marketing Science, 33(2), 165-187. http://dx.doi.org/10.1287/mksc.2013.0815

Claro, D. P., \& Ramos, C. (2018). Sales intrafirm networks and the performance impact of sales cross-functional collaboration with marketing and customer service. Journal of Personal Selling E⿱E Sales Management, 38(2), 172-190. https://doi.org/10.1080/08853134.2018.1437353

Claro, D. P., \& Kamakura, W.A. (2017). Identifying sales performance gaps with internal benchmarking. Journal of Retailing, 93(4), 401-419. https://doi.org/10.1016/j.jretai.2017.08.001

Claro, D. P., Laban Neto, S., \& Claro, P. B. D. O. (2013). The enhancing impact of friendship networks on sales managers' performance. Brazilian Administration Review, 10(2), 158-175. https://doi.org/10.1590/S180776922013000200004 .

Claro, D. P., Ramos, C., Gonzalez, G. R., \& Palmatier, R. W. (2020). Dynamic effects of newcomer salespersons' peer relational exchanges and structures on performance. International Journal of Research in Marketing, 37(1), 7492. https://doi.org/10.1016/j.ijresmar.2019.07.006

Cooper, M. J., \& Budd, C. S. (2007). Tying the pieces together: A normative framework for integrating sales and project operations. Industrial Marketing $\quad$ Management, $\quad 36(2), \quad$ 173-182. https://doi.org/10.1016/j.indmarman.2006.03.005

Davies, C. (2020). The ultimate guide to sales prospecting: Tips, techniques, and tools to succeed. HubSpot. Retrieved from https://blog.hubspot.com/sales/prospecting

Feng, H., Morgan, N. A., \& Rego. L. L. (2015). Marketing department power and firm performance. Journal of Marketing, 79(5), 1-20. https://doi.org/10.1509/jm.13.0522

Gonzalez, G. R., \& Claro, D. P. (2019). How intrafirm intermediary salespeople connect sales to marketing and product development. Journal of the Academy of Marketing Science, 47(5), 795-814. https://doi.org/10.1007/s11747-019-00656-8

Gonzalez, G. R., Claro, D. P., \& Palmatier, R. W. (2014). Synergistic effects of relationship managers' social networks on sales performance. Journal of Marketing, 78(1), 76-94. https://doi.org/10.1509/jm.11.0431

Götz, O., Hoelter, A. K., \& Krafft, M. (2013). The role of sales and marketing in market-oriented companies. Journal of Personal Selling $\mathcal{E}$ Sales Management, 33(4), 353-371. https://doi.org/10.2753/PSS0885-3134330401

Hartmann, N. N., Wieland, H., \& Vargo, S. L. (2018). Converging on a new theoretical foundation for selling. Journal of Marketing, 82(2), 1-18. https://doi.org/10.1509/jm.16.0268

Johnson, J. S., \& Friend, S. B. (2015). Contingent cross-selling and up-selling relationships with performance and job satisfaction: An MOA-theoretic examination. Journal of Personal Selling $\mathscr{E}$ Sales Management, 35(1), 51-71. https://doi.org/10.1080/08853134.2014.940962

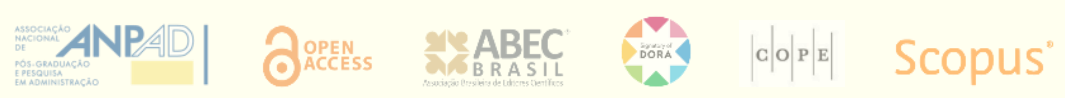


Jolson, M. A., \& Wotruba, T. R. (1992). Selling and sales management in action: Prospecting: A new look at this old challenge. Journal of Personal Selling $\mathcal{E}$ Sales Management, 12(4), 59-66. https://doi.org/10.1080/08853134.1992.10753928

Koponen, J., Julkunen, S., \& Asai, A. (2019). Sales communication competence in international B2B solution selling. Industrial Marketing Management, 82, 238-252. https://doi.org/10.1016/j.indmarman.2019.01.009

Lacoste, S. (2018). From selling to managing strategic customers-a competency analysis. Journal of Personal Selling $\mathcal{E}$ Sales Management, 38(1), 92-122. https://doi.org/10.1080/08853134.2018.1426991

Lemon, K. N., \& Verhoef, P. C. (2016). Understanding customer experience throughout the customer journey. Journal of Marketing, 80(6), 69-96. https://doi.org/10.1509/jm.15.0420

Locke, E. A., Latham, G. P. \& Erez, M. (1988). The determinants of goal commitment. Academy of Management Review, 13(1), 23-39. https://doi.org/10.5465/amr.1988.4306771

Locke, E. A., Smith, K. G., Erez, M., Chah, D.-O., \& Schaffer, A. (1994). The effects of intra-individual goal conflict on performance. Journal of Management, 20(1), 67-91. https://doi.org/10.1177/014920639402000104

Loritz, M. (2019, April). Helsinki-based Leadfeeder raises $€ 3.1$ million to automate B2B lead generation. EU Startups. Retrieved from https://www.eu-startups.com/2019/04/helsinki-based-leadfeeder-raises-e3-1-million-toautomate-b2b-lead-generation/

Michiels, I. (2009). Lead lifecycle management: Building a pipeline that never leaks (Research Report), Aberdeen Group. Retrieved from https://www.ontargetpartners.com/wpcontent/uploads/2010/02/Building_A_Pipeline_That_Never_Leaks_by_AberdeenGroup.pdf

Mitrega, M., Forkmann, S., Ramos, C., \& Henneberg, S. C. (2012). Networking capability in business relationships: Concept and scale development. Industrial Marketing Management, 41(5), $739-751$. https://doi.org/10.1016/j.indmarman.2012.06.002

Monteiro, R. B., \& Vieira, V. A. (2016). Team potency and its impact on performance via self-efficacy and adaptability. Brazilian Administration Review, 13(1), 98-119. http://dx.doi.org/10.1590/1807. 7692 bar2016150283

Morgan, N. A., Feng, H., \& Whitler, K. A. (2018). Marketing capabilities in international marketing. Journal of International Marketing, 26(1), 61-95. https://doi.org/10.1509/jim.17.0056

Paschen, J., Wilson, M., \& Ferreira, J. J. (2020). Collaborative intelligence: How human and artificial intelligence create value along the B2B sales funnel. Business Horizons, 63(3), 403-414. https://doi.org/10.1016/j.bushor.2020.01.003

Peterson, R. M., Rodriguez, M., \& Krishnan, V. (2011). CRM and sales pipeline management: Empirical results for managing opportunities. Marketing Management Journal, 21(1), 60-70. Retrieved from http://www.mmaglobal.org/publications/MMJ/MMJ-Issues/2011-Spring/MMJ-2011-Spring-Vol21-Issue1Peterson-Rodriguez-Krishnan-pp60-70.pdf

Pöyry, E., Parvinen, P., \& McFarland, R. G. (2017). Generating leads with sequential persuasion: Should sales influence tactics be consistent or complementary? Journal of Personal Selling EO Sales Management, 37(2), 89-99. https://doi.org/10.1080/08853134.2016.1275973

Raman, P., Wittmann, C. M., \& Rauseo, N. A. (2006). Leveraging CRM for sales: The role of organizational capabilities in successful CRM implementation. Journal of Personal Selling $\mathcal{E}$ Sales Management, 26(1), 39-53. https://doi.org/10.2753/PSS0885-3134260104

Román, S., \& Iacobucci, D. (2010). Antecedents and consequences of adaptive selling confidence and behavior: A dyadic analysis of salespeople and their customers. Journal of the Academy of Marketing Science, 38(3), 363-382. https://doi.org/10.1007/s11747-009-0166-9

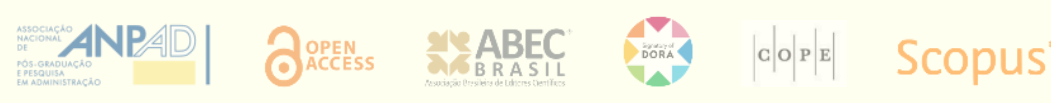


Sabnis, G., Chatterjee, S. C., Grewal, R., \& Lilien, G. L. (2013). The sales lead black hole: On sales reps' follow-up of marketing leads. Journal of Marketing, 77(1), 52-67. https://doi.org/10.1509/jm.10.0047

Saegert, J., \& Hoover, R. J. (1980). Sales managers and sales force feedback: Information left in the pipeline. Journal of the Academy of Marketing Science, 8(1-2), 33-39. https://doi.org/10.1007/BF02721970

Schmitz, H. (2020, March). 10 problemas que você pode resolver com SLA entre marketing e vendas. Sales Hackers. Retrieved from https://saleshackers.com.br/blog/sla-entre-marketing-e-vendas/

Söhnchen, F., \& Albers, S. (2010). Pipeline management for the acquisition of industrial projects. Industrial Marketing Management, 39(8), 1356-1364. https://doi.org/10.1016/j.indmarman.2010.04.001

Spencer, J. (2019, October). How marketers can tackle sales pipeline ownership. Forbes. Retrieved from https://www.forbes.com/sites/forbesbusinessdevelopmentcouncil/2019/10/02/how-marketers-can-tackle-salespipeline-ownership/\#1a75525f572f

Strong, E. K. (1925). The psychology of selling and advertising. New York: McGraw-Hill.

Venkatesan, R., Petersen, J. A., \& Guissoni, L. (2018). Measuring and managing customer engagement value through the customer journey. In R. W. Palmatier, V. Kumar, \& C. M. Harmeling (Eds.), Customer engagement marketing (pp. 53-74). London: Palgrave Macmillan.

Verbeke, W., Belschak, F., \& Bagozzi, R. P. (2004). Exploring emotional competence: Its effects on coping, social capital, and performance of salespeople [ERS-2004-014-ORG]. ERIM Report Series Research in Management, Rotterdam, Netherlands. Retrieved from https://ideas.repec.org/p/ems/eureri/1174.html

Verbeke, W., Dietz, B., \& Verwaal, E. (2011). Drivers of sales performance: A contemporary meta-analysis. Have salespeople become knowledge brokers? Journal of the Academy of Marketing Science, 39(3), 407-428. https://doi.org/10.1007/s11747-010-0211-8

Vieira, V. A., de Almeida, M. I. S., Agnihotri, R., Silva, N., \& Arunachalam, S. (2019). In pursuit of an effective B2B digital marketing strategy in an emerging market. Journal of the Academy of Marketing Science, 47(6), 10851108. https://doi.org/10.1007/s11747-019-00687-1

Vieira, V. A., Faia, V. S., Boles, J., Marioti, B. R., \& Pereira, R. C. (2019). The role of self-regulatory mode on acquisition-retention ambidexterity. Journal of Business $\mathcal{E}$ Industrial Marketing, 34(8), 1813-1826. https://doi.org/10.1108/JBIM-03-2018-0114

Vieira, V. A., Negreiros, L. F., Agnihotri, R., \& Bakeshloo, K. A. (2020). Perceptual differences regarding leadership between the store manager and employees and its impact on frontline sales performance: A research note. Journal of Retailing (in press). https://doi.org/10.1016/j.jretai.2020.11.004

Vieira, V. A., Perin, M. G., \& Sampaio, C. H. (2018). The moderating effect of managers' leadership behavior on salespeople's self-efficacy. Journal of Retailing and Consumer Services, 40, $150-162$. https://doi.org/10.1016/j.jretconser.2017.09.010

Voskresensky, V. (2019, April). How sellers can accelerate their sales cycles with a more human touch. Forbes. Retrieved from https://www.forbes.com/sites/forbestechcouncil/2019/04/02/how-sellers-can-accelerate-theirsales-cycles-with-a-more-human-touch/\#35774f6de5c0

Weitz, B. A., \& Bradford, K. D. (1999). Personal selling and sales management: A relationship marketing perspective. Journal of the Academy of Marketing Science, 27(2), 241. https://doi.org/10.1177/0092070399272008

Wiesel, T., Pauwels, K., \& Arts, J. (2011). Marketing's profit impact: Quantifying online and off-line funnel progression. Marketing Science, 30(4), 604-611. Retrieved from https://www.jstor.org/stable/23012014

Zoltners, A. A., \& Sinha, P. (1980). Integer programming models for sales resource allocation. Management Science, 26(3), 242-260. http://dx.doi.org/10.1287/mnsc.26.3.242

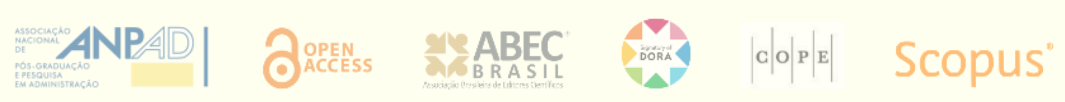




\section{Authors' contributions}

$1^{\text {st }}$ author: project administration - (lead), conceptualization - (lead), writing - (equal), resources - (equal). $2^{\text {nd }}$ author: supervision - (lead), visualization - (lead), writing - (equal), resources - (equal).

\section{Authors}

Valter Afonso Vieira*

Universidade Estadual de Maringá

Av. Colombo, n. 5790, Zona 07, 87020-900, Maringá, PR, Brazil

valterafonsovieira@gmail.com

(iD) https://orcid.org/0000-0002-4129-3343

\section{Danny Pimentel Claro}

INSPER Instituto de Ensino e Pesquisa

Rua Quatá, n. 300, Vila Olímpia, 04546-042, São Paulo, SP, Brazil

danny@insper.edu.br

(iD) https://orcid.org/0000-0002-8387-0938

* Corresponding author

Peer review is responsible for acknowledging an article's potential contribution to the frontiers of scholarly knowledge on business or public administration. The authors are the ultimate responsible for the consistency of the theoretical references, the accurate report of empirical data, the personal perspectives, and the use of copyrighted material.

This content was evaluated using the double-blind peer review process. The disclosure of the reviewers' information on the first page is made only after concluding the evaluation process, and with the voluntary consent of the respective reviewers. 